\title{
Elleke Boehmer and Rosinka Chaudhuri, eds., The Indian Postcolonial. A Critical Reader
}

\section{Alexis Tadié}

\section{OpenEdition}

1 Journals

Electronic version

URL: https://journals.openedition.org/ces/6015

DOI: $10.4000 /$ ces. 6015

ISSN: 2534-6695

Publisher

SEPC (Société d'études des pays du Commonwealth)

\section{Printed version}

Date of publication: 1 April 2012

Number of pages: 109-110

ISSN: 2270-0633

\section{Electronic reference}

Alexis Tadié, "Elleke Boehmer and Rosinka Chaudhuri, eds., The Indian Postcolonial. A Critical Reader", Commonwealth Essays and Studies [Online], 34.2 | 2012, Online since 19 April 2021, connection on 23 July 2021. URL: http://journals.openedition.org/ces/6015 ; DOI: https://doi.org/10.4000/ces.6015

This text was automatically generated on 23 July 2021 .

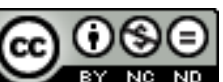

Commonwealth Essays and Studies is licensed under a Licence Creative Commons Attribution - Pas d'Utilisation Commerciale - Pas de Modification 4.0 International. 


\title{
Elleke Boehmer and Rosinka Chaudhuri, eds., The Indian Postcolonial. A Critical Reader
}

\author{
Alexis Tadié
}

\section{REFERENCES}

Elleke Boehmer and Rosinka Chaudhuri, eds. The Indian Postcolonial. A Critical Reader.

London: Routledge, 2011. 366 p. ISBN (pb): 978-0-415-56766-4. £25.99

1 This absorbing anthology springs from a feeling of discontent with the uses of postcolonialism in recent academic practice. Over the years, the concept has become rather fuzzy, encompassing everything and anything, and being used in universities as an excuse for marketing the "other." The territory of postcolonialism has extended beyond recognition. Going against the grain, the editors of this anthology, and indeed the authors whose texts are offered to the reader, seek firmly to relocate postcolonial theory and practice. They wish to address the dilution of the heuristic power of postcolonial concepts by concentrating on specific conditions of analysis. The fact that this move focuses on India may seem surprising because one of the dominant features of postcolonial analysis in recent years has been to address the postcolonial condition beyond national boundaries and to offer a form of universalism - which was also aimed at avoiding the pitfalls of the official narratives of post-Independence national states. The theoretical gesture of the editors is at the same time unsurprising because of the influence of Indian historians (of the subaltern studies group for instance), and indeed of Indian novelists, on the elaboration of the concepts of postcolonial theory. But the editors' point lies elsewhere: "this reader intends rather to look at how the postcolonial translates into the specificities of Indian history and culture in critical reflections of the near-contemporary moment." This is therefore neither a question of genealogy nor of national retreat, but rather of the local appropriations of postcolonial concepts. Although the anthology includes authors who are recognisably part of "postcolonial 
studies," and have, in some cases, such as Robert C. Young or Gayatri Spivak, helped shape the field, a number of writers have worked outside the postcolonial paradigm, their work focusing mainly on India. A number of them have been working within the Indian academic world for a number of years, in such projects as the "subaltern studies," represented here by some of its most influential historians (Partha Chatterjee, Dipesh Chakrabarty, and of course Ranajit Guha). But others, although part of the Indian academic world, have not necessarily been identified with a "project." Ashis Nandy, whose pioneering work on the psychology of colonialism was extremely influential in India, Amit Chaudhuri, who is a novelist and an essayist rather than a professional academic, Udaya Kumar, who works on English literature as well as on vernacular cultures in India, are some of the names that reflect the editors' desire to give a voice to the variety of Indian practice in the field. There is thus no sense of "writing back" in this collection, but a desire to bring to the reader the inflections of postcoloniality in a specific - here, Indian - context. Out of the sixteen chapters, twelve have previously appeared elsewhere.

2 The anthology is broadly organised into four parts entitled "visual cultures," "translating cultural traditions," "the ethical text," and "global/cosmopolitan worlds." Any reader of the anthology will be struck by the variety of approaches and subjects and indeed periods of history under consideration - the "Indian postcolonial" is by no means confined to post-Independence days. The anthology devotes four essays to visual culture (from the use of images in educational books, to questions of delineation between the religious and the artistic, to the cinema of Satyajit Ray and to the political power of film stars). It does not examine the (contemporary) literatures of India, but literature comes into focus in some of the contributions (Gayatri Spivak's essay on Coetzee and Tagore, Amit Chaudhuri's reflections on cosmopolitanism, Santanu Das's fascinating analysis of Indian responses to the First World War) and provides modes of understanding the structure of colonialism in others (such as Ranajit Guha's chapter on Calcutta).

3 A number of the essays are concerned with questions of practice, for instance in the section on the "ethical text" where the ethics of reading are brought to light. But ethics obviously extend beyond texts - Ashis Nandy's contribution, anthologized from an earlier book, examines the psychology of humiliation. His controversial but fascinating thesis is that for humiliation to obtain, the humiliated must, to some degree, express a feeling of having been humiliated. In this sense it works somewhat like blasphemy which is entirely dependent on the recognition by the injured party that there has indeed been blasphemy. Nandy's exploration of humiliation centers on India, and in particular on the Dalit community, but extends far beyond, addressing moments in Gandhi's time in South Africa, looking at the question of slavery in America or reminding us that Indian Jews in Israel feel compelled to tell a tale of two thousand years of oppression whereas the community back home always described a life of toleration and peaceful coexistence. Although the question of humiliation is one that is essential in India to understand the plight of the Dalits or some stories of post-Partition violence and rape, Nandy reflects on the fundamental structure as much as on instances of humiliation. His analysis is rooted in India but elicits a meditation which ranges far beyond the borders of the country. Ranajit Guha's chapter on Calcutta, which concludes the anthology, displays the fusion between a literary exploration of India and one that is based on the social sciences. The chapter outlines through some 
nineteenth-century texts the ways in which the literature of the time enables us to perceive the development of the metropolis. It reflects on the nature and treatment of the "everyday" and the "now" in the city. It brings to light the total disjunction between an official time, that of the imperial power, and an indigenous time, marked by festival, which is a communitarian experience for the colonized.

4 Readers of this anthology will find much to read and much to reflect upon; they will be (re)acquainted with the diversity and richness of Indian social sciences and humanities; they will be convinced by the necessity to refocus and relocate the work of postcolonial theory.

\section{AUTHORS}

\section{ALEXIS TADIÉ}

Alexis TADIÉ is Professor of English Literature at the University of Paris 4 - Sorbonne and a fellow of the Institut Universitaire de France. He has written on colonial and postcolonial literatures, as well as on the eighteenth-century novel. In 2012-3, he is visiting fellow at All Souls College, Oxford. 